\title{
Digital Comics as A Media in EFL Reading Classrooms
}

\author{
Atika Diyah Saputri 1, Sunardi ${ }^{2}$, Akhmad Arif Musadad 3 \\ DOI: 10.35445/alishlah.v13i2.758
}

\section{Article Info}

Keywords:

Digital comics;

Media;

L2 reading

Kata kunci:

Komik digital;

Media;

$L 2$ reading

\section{Abstract}

This study aims to determine student perceptions of Digital Comics as a learning media in senior high school in Surakarta. The design of this study used a survey with a questionnaire given to 80 students of class XI randomly. Data collection techniques using questionnaires. A questionnaire is used to collect data, which is distributed to student population samples. The technique for collecting data is to distribute questionnaires and then analyze the results quantitatively using percentages and analysis tools. The results showed that $79.2 \%$ of students were not familiar with digital comics. Learning media can be seen in that $68 \%$ use PowerPoint, $24 \%$ use books, and $8 \%$ use learning videos. Students' perceptions of digital comics' use as a learning media showed that $93 \%$ of students agreed, and $7 \%$ disagreed with using digital comics in the L2 reading classrooms. This study implies that digital comics' use in the EFL reading classrooms is an alternative activity and provides fun learning for students.

\begin{abstract}
Abstrak
Penelitian ini bertujuan untuk mengetahui persepsi siswa terhadap penggunaan Digital Comic sebagai media pembelajaran di Sekolah Menengah Atas Surakarta. Desain penelitian ini meggunakan survei dengan kuesioner yang diberikan kepada 80 siswa kelas XI secara acak. Kuesioner digunakan untuk mengumpulkan data yang disebarkan kepada siswa. Teknik pengumpulan data adalah dengan menyebarkan angket kemudian menganalisis hasilnya secara kuantitatif menggunakan persentase dan alat analisis. Teknik pengumpulan data menggunakan Kuesioner. Hasil penelitian menunjukkan bahwa 79,2\% siswa belum familiar dengan komik digital. Media pembelajaran yang sering digunakan dapat diketahui bahwa 68\% menggunakan PowerPoint, 24\% menggunakan media buku, dan $8 \%$ menggunakan video pembelajaran. Persepsi siswa terhadap penggunaan komik digital sebagai media pembelajaran menunjukkan bahwa 93\% siswa setuju dan $7 \%$ tidak setuju apabila komik digital di terapkan di kelas membaca L2 ini menyiratkan bahwa penggunaan komik digital di kelas EFL reading menjadi salah satu alternatif dan memberikan pembelajaran yang menyenangkan kegiatan untuk siswa.
\end{abstract}

${ }^{1}$ Universitas Sebelas Maret, Indonesia
Email: atikasaputri88@student.uns.ac.id
2 Universitas Sebelas Maret, Indonesia
Email: Sunardi.ipuns@gmail.com
3 Universitas Sebelas Maret, Indonesia
Email: akhmadarifmusadad@staff.uns.ac.id

Vol.13 (2) August, 2021

Received: July 7, 2021; Received in revised form: July 29, 2021; Accepted: August 9, 2021; Available online: August 21, 2021

This is an open access article under a Creative Commons Attribution-NonCommercial-ShareAlike 4.o International License 


\section{INTRODUCTION}

The ability to understand English is necessary for terms of further improving language skills. One of the students' 21st-century abilities in English is reading. The integration of 21st-century skills in English language learning is essential. The 21st-century challenges are finished with the mastery of the English language. Reading is an essential skill for success in real life. The ability foreign language reading presented a daunting challenge for language learners. Iranian students studying English mastery (L2) were asked to spend one lesson period per week, over 15 weeks, reading material from the structure of a series of English teaching reading materials in this project. This method is concerned with the practice of extensive reading (ER). It is widely acknowledged that EFL students must spend a significant amount of time interacting with written material in L2 (Namaziandost, Esfahani \& Ahmadi, 2019).

Reading accounts for a large portion of our reading comprehension, writing style, vocabulary, spelling, and advanced grammatical competence (Krashen, 1994). Therefore, foreign language learners need to be exposed to the foreign language environment. In reading, students can relate knowledge from the first language they have mastered to understanding English texts. In this case, extensive reading of written texts helps in language acceptance by students (Huang, 2015). However, some students felt that reading was fun less because they had difficulty understanding writing, main ideas, and answering questions.

Currently, technological developments can be considered in teaching English in increasing student interaction (Licorish et al., 2018; Santosa, 2017). The integration of technology in learning can help the student learning process. Technological developments can change human life. One of these changes is in the education sector. However, the current COVID-19 pandemic has brought changes in the implementation of the learning process. Teachers are required to do online learning. The raises concerns about the effectiveness of online learning. Therefore, teachers are expected to be able to become facilitators in supporting the student learning process. The teacher focuses on fulfilling the material, not only the mastery of learning materials that students must achieve. In addition, difficulties in learning to read during the pandemic were caused by students' lack of interest in reading. In addition, there is no digital media support used by teachers.

Digital media integrated with the L2 reading class. One of the technology-based learning media that is currently developing is digital comics. Digital comics can be the best alternative to using tools in the reading classroom. Digital comics can easily be found on the internet and smartphone applications and are not recognized yet as educational tools. Therefore, digital comics in L2 reading classes are not typical and even considered non-academic. Currently, comics are developing into digital forms. The advantages of digital comics are that they are durable, inexpensive, interactive, and easily accessible (McCloud, 2000).

Comics are defined as pictures and other symbols in a particular order to convey information and achieve aesthetic responses from readers (McCloud, 2008: 9). Digital comics are suitable learning materials in L2 reading classes. Digital comics aim to motivate students in the process of accepting language skills, imagination, and cultural experiences in making stories (Vassilikopoulou, Retalis, Nezi \& Boloudakis, 2011). Thus, observers can provide a systematic picture that links digital comics with learning objectives. Comics are described as a creative process in finding solutions to more complex problems.

Some researchers pay much attention to the digital comics used in L2 reading classes. Collaboratively using comics can make learning better and more focused (Dallacqua, 2020). Comics can increase students' literacy skills and change in the 21st century (Issa, 2018). Therefore, comics can foster enthusiasm and enrich students' literacy skills. The others Researchers (Lazarinis, Mazaraki, Verykios, \& Panagiotakopoulos, 2015) apply digital comics as alternative learning media. Therefore, this study tries to investigate digital comics as digital media in the reading class. The research questions are as follows: What types of learning media do students often use in reading classrooms?; What is students' experience in using digital comics in reading classrooms? How do 
students perceive digital comics in reading classrooms?. Therefore, further research is still needed to fulfill the right potential and challenge digital technology's application in the learning process. Various advantages and positive impacts of implementing digital media in the learning process mentioned above that digital media is one of the potential technologies that can apply to increase learning effectiveness.

\section{METHODS}

This study aims to determine student perceptions of Digital Comics as a medium of learning in high school schools in Surakarta. The research was conducted in a private high school in Surakarta. The participants are students of XI grade with a total sample of 80 students. Students are on average $17-18$ years old, and $78 \%$ are girls.

This research is descriptive. Descriptive research is used to explain the characteristics of a specific event. It is more concerned with what happened rather than how or why something happened (Nassaji, 2015), and the survey is used to collect data. The data collection method is a survey using a questionnaire distributed to students. Then the results are analyzed quantitatively using percentages and analytical tools. A questionnaire is a written instrument consisting of several questions or statements answered by the respondent (Brown, 2001, p. 6). The initial stage of the research was started by giving questionnaires to 80 students. The research focus is on students' perceptions of digital comic media in the reading class. The questionnaire consisted of the types of learning media, students' interest in learning media, and student's perceptions of the use of digital comics, and the student's reasons for choosing digital comics. After that, the data were analyzed quantitatively using percentages so that the data was obtained clearly.

\section{FINDINGS AND DISCUSSION}

This section will present the research findings concerning students' experiences with digital comics, types of learning media, and students' perceptions of the use of digital comics. This section will go over how digital comic media was used in the L2 reading classroom.

\section{Types of Students' Learning Media}

The results show that the types of media are PowerPoint at $68 \%$, books at $24 \%$, and videos at $8 \%$. PowerPoint used by teachers as a medium in delivering learning materials is considered easier to make and does not require much time in the manufacturing process.

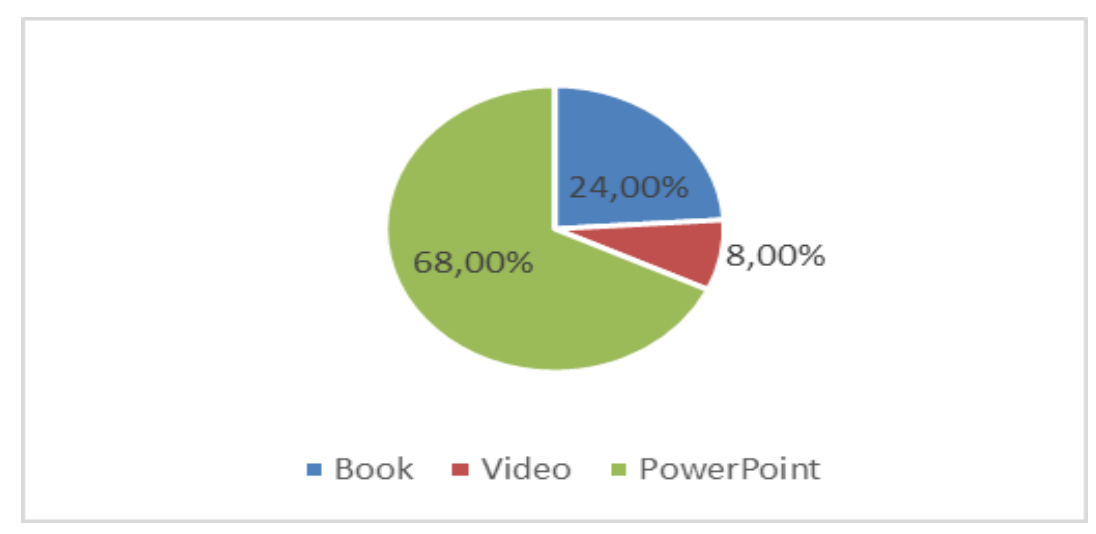

\section{Figure 1. Types of Learning Media}

Based on the study results, it was found that almost some teachers had not implemented the use of digital comics in the reading class and tended to use other learning media. Therefore, students have difficulty in accepting and understanding the material presented by the teacher. Students feel bored during the learning process because the learning media used are not based on the topics discussed. Digital learning media is a potential medium when applied in online learning. According to previous research, One of the most critical components of the learning process in schools is 
instructional media (Muteheli, 2017);(Pernanda et al., 2018). According to (Ling \& Yunus, 2016), technology adds value that can affect the quality of language education. Engeness (2020) explained that technology encourages students' conceptual understanding and facilitates teachers' learning.

\section{Students' Experience of the Use of Digital Comics}

In this section, the researcher will explain students' experiences related to digital comics media. Based on figure 2, the researchers obtained findings that have been filled by students showing that $79.2 \%$ of students do not know yet and understand the existence of digital comics as learning media. Furthermore, 20.8\% know the use of digital comics as a media. Interviews with students admitted that their teachers had never applied digital comics as learning media in L2 reading classes. It concluded that almost all students do not have any learning experience using digital comics as a learning medium during online learning.

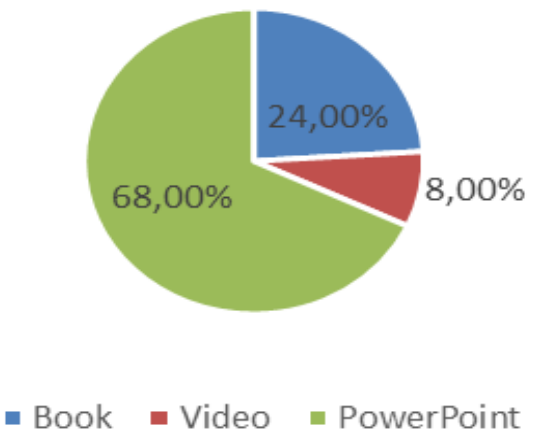

Figure 2. The Students' Familiarity with The Use of Digital Comics

Teachers are expected to be able to integrate the use of digital media in online learning during COVID 19 pandemic. Success in the online learning process requires knowledge and skills (Konig, Jager-Biela, \& Glutsch, 2020). Previous research also explained that language skills for students could be obtained by designing digital comics as a learning media (Vassilikopoulou, Retalis, Nezi \& Boloudakis, 2011) and as the primary way of accessible text-based literacy (Issa, 2018). Adaptive teaching determines how much quality education is. According to Kaiser \& Konig (2019), these findings reinforce previous research that educational goals can be achieved by emphasizing the meaningfulness and competence of teacher quality.

\section{Students' Perception of the Use of Digital Comic}

As shown in Figure 3, students' perceptions of digital comics media showed that $93 \%$ of students agree to adopt digital comics in their reading class. In comparison, only $7 \%$ of students disagreed. According to their responses, students have never used this type of learning media in L2 reading class. Therefore, students' perception of digital comic media is very high. Students agree with the development of digital comics as learning media in the reading classroom.

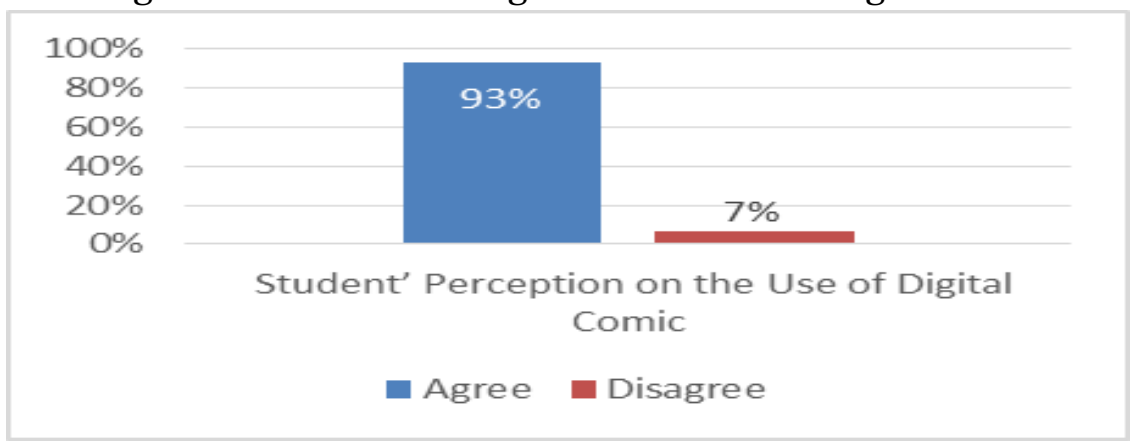

Figure 3. Student' Perception of the Use of Digital Comic 
As shown in figure 4, the researcher will explain why students prefer digital comics over others. As in the picture below, the researchers found several reasons for digital comics as online learning media. Some findings show that $41.9 \%$ of students consider digital comics to contain various materials and information, $39.5 \%$ of students think digital comics have an attractive appearance. It makes students prefer digital comics. An attractive appearance in terms of visualizing characters, the variety of features, and exciting evaluation materials make the media not monotonous and boring. Meanwhile, $18.6 \%$ of students think that digital comics are interactive. It can be explained that this digital comics media requires a player's role in operating it so that the player can choose the desired learning theme. The students recognize that digital comics are interactive because many stories can be expressed through animation and pictures.

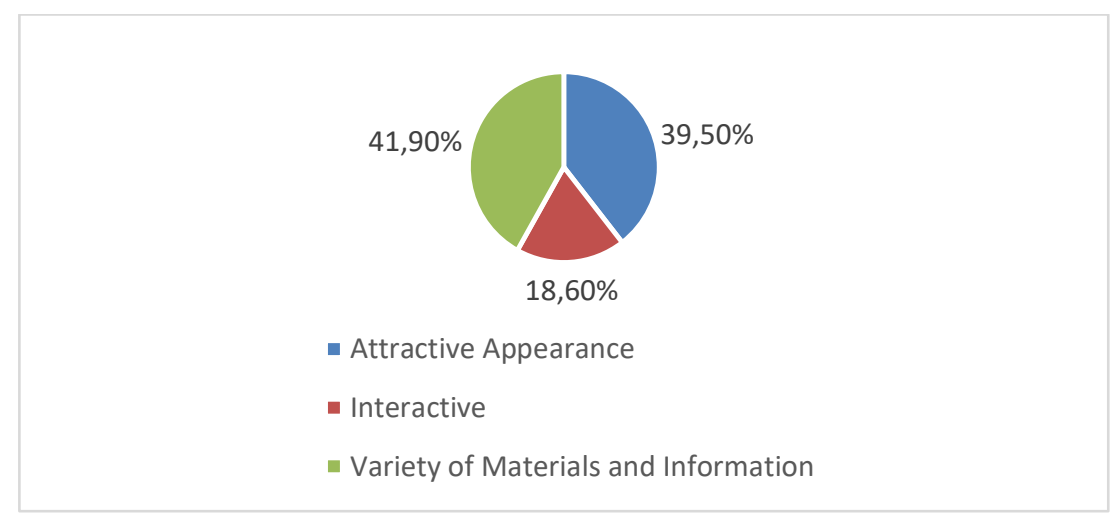

\section{Figure 4. Students' Reason for Choosing Digital Comic Media}

The use of digital comics can provide a new experience in learning, so it must also learn how to operate the media. According to Henderson, Selwyn \& Aston (2017), digital media can be facilitating task completion, flexibility, and implementation of learning. According to previous research, the student learning process can be better if comics are done collaboratively (Dallacqua, 2020). Information and materials contained in digital comic media can be adjusted based on the theme and learning objectives. The selection in terms of appearance, visual design, and animated comic characters also affects students' understanding of the learning objectives to be achieved. This shows that comics are different from other learning media.

The process of using learning multimedia can be likened to building their knowledge (Shi, 2017). In addition, it can compose more material than various components. Students are also able to understand the learning material because the media is interactive entirely. The results of the findings are technology-based potential in the learning process (Yue, 2017). Students have time flexibility in its use because it can be used anytime and anywhere in the learning process. Students are familiar with the use of technology, especially android-based so that they can create fun learning. Technological advancements can be combined with the benefits of comics to create learning media beneficial to students. Digital comic media is one of them. Digital comics are media with dynamic illustrations and storylines that can quickly adapt to technological advancements (Ulfa et al., 2016); (Wang, 2016).

\section{CONCLUSION}

In general, this study aims to describe students' perceptions of digital comics during a reading at the high school level. The study results explained that $79.2 \%$ of students were not familiar with digital comics as learning media in reading classrooms. The learning media used by students during online learning shows that $8 \%$ use books, $24 \%$ of students use learning videos, and $68 \%$ use PowerPoint. Students' perception of digital comics learning media shows that $92.9 \%$ of students agree that digital comics are one of the innovative media that can be integrated with the reading 
class. The use of digital comics can improve the quality, motivation, and achievement of students in the classroom. According to the researchers, the use of digital comics in learning to read will positively impact student performance. Later on, the results of this study are expected to be used as material for evaluation and consideration for the sustainability of developing learning media products, considering that there is no student understanding of the use of learning media. The pedagogical implication is that the availability of supporting facilities can facilitate and provide new experiences for teachers in creating an effective learning process. Teachers must understand the selection of media and learning resources as a reference in the learning process. However, our findings are still based on narrow observations, so this area still requires further research.

\section{REFERENCES}

Brown, H. G. (2001). Teaching by principles: Interactive approach to language pedagogy. New York, NY: Pearson Longman.

Dallacqua, A. K. (2020). Reading comics collaboratively and challenging literacy norms. Literacy research and instruction, 59(2), 169-190. https://doi.org/10.1080/19388071.2019.1669746

Engeness, I. (2020). Developing teachers' digital identity: towards the pedagogic design principles of digital environments to enhance students' learning in the 21st century. European Journal of Teacher Education, 2(1), 1-13. https://doi.org/10.1080/02619768.2020.1849129

Henderson, M., Selwyn, N., \& Aston, R. (2017). What works and why? Student perceptions of 'useful'digital technology in university teaching and learning. Studies in Higher Education, 42(8), 1567-1579. https://doi.org/10.1080/03075079.2015.1007946

Huang, Y. C (2015). Why don't they do it? A study on the implementation of extensive reading in Taiwan. Cogent Education, 2(1), 1-13. https://doi.org/10.1080/02619768.2020.1849129.

Issa, S. (2018). Comics in the English classroom: a guide to teaching comics across English studies. Journal of Graphic Novels \& Comics, 9(4), 310-328. https://doi.org/10.1080/21504857.2017.1355822

Krashen, S. (1994). The input hypothesis and its rivals. In N. C.Ellis (Ed.), Implicit and explicit learning of languages (pp.45-77). London: Academic Press.

Konig, J., Jäger-Biela D. J., \& Glutsch, N. (2020). Adapting to online teaching during COVID-19 school closure: teacher education and teacher competence effects among early career teachers in Germany, European Journal of Teacher Education. 43(4), 608-622. https://doi.org/10.1080/02619768.2020.1809650

Kurniawati, I. D., \& Nita, S. (2018). Media pembelajaran berbasis multimedia interaktif untuk meningkatkan pemahaman konsep mahasiswa [Interactive multimedia-based learning media to enhance students' concepts understanding]. DoubleClick: Journal of Computer and Information Technology, 1(2), 68-75. http://doi.org/10.25273/doubleclick.v1i2.1540

Lazarinis., F., Mazaraki, A., Verykios, V., \& Panagiotakopoulos, C. (2015). E-comics in teaching:Evaluating and using comic strip creator tools for educational purposes. 2015 1oth International Conference on Computer Science \& Education, 305-309. https://doi.org/10.1109/ICCSE.2015.7250261

Licorish, S. A., Owen, H. E., Daniel, B., \& George, J. L. (2018). Students' perception of Kahoot!'s influence on teaching and learning. Research and and practice in Technology Enhanced Learning, 13(1), 1-23.

Ling, A. T., \& Yunus, M. M. (2016). Secondary ESL Teachers' Receptiveness towards ICT Integration. Asian EFL Journal, 7(March), 5-18. Retrieved from http://www.elejournals.com

McCloud, S. (2008). Reinventing Comics (Mencipta Ulang Komik). Kepustakaan Populer Gramedia McCloud, S. (2000). Reinventing Comics. 1st Perennial Ed ed. New York, NY: Harper Collins.

Namaziandost, E., Esfahani, F.R., \& Ahmadi, S. (2019) Varying levels of difficulty in L2 reading materials in the EFL classroom: Impact on comprehension and motivation, Cogent Education, 6:1, 1615740, DOI: 10.1080/2331186X.2019.1615740.

Nassaji, H. (2015). Qualitative and descriptive research: Data type versus data analysis. Editorial $\begin{array}{llll}\text { Language Teaching } & \text { Research, } & 19(2), & 129-132 .\end{array}$ https://doi.org/10.1177\%2F1362168815572747

Santosa, M. H. (2017). Learning approaches of Indonesian EFL Gen Z students in a Flipped Learning context. Journal on English as a Foreign Language, 7(2), 183-208. https://doi.org/10.23971/jefl.v7i2.689 
Shi, $X$. (2017). Application of multimedia technology in vocabulary learning for engineering students. International Journal of Emerging Technologies in Learning, 12(1), 21-31. https://doi.org/10.3991/ijet.v12io1.6153

Ulfa, S., Putri, V., Budiardjo, H., \& Prayitno, S. (2016). Perancangan Buku Komik Ludruk Berbasis Ilustrasi Digital Guna Mengenalkan Kembali Kesenian Tradisional kepada Remaja. Jurnal Art Nouveau, 5(2), 329-338.

Vassilikopoulou, M., Retalis, S., Nezi, M., \& Boloudakis, M. (2011). Pilot use of digital educational comics in language teaching. Educational Media International, 48(2), 115-126. https://doi.org/10.1080/09523987.2011.576522

Wang, J. (2016). On the Application of Modern Comics Formal Language and Digital Media Technology in Traditional Comics. International Conference on Humanity, Education and Social Science, 339-342. https://doi.org/10.2991/ichess-16.2016.74

Yue, N. (2017). Computer multimedia assisted English vocabulary teaching courseware. International Journal of Emerging Technologies in Learning, 12(12), 67-78. https://doi.org/10.3991/ijet.v12.i12.7955 